\title{
Mineralogy of Selected Sedimentary Interbeds at or near the Idaho National Engineering Laboratory, Idaho
}

\author{
By Michael F. Reed and Roy C. Bartholomay
}

\section{U.S. GEOLOGICAL SURVEY \\ Open-File Report 94-374}

\section{DISCLAIMER}

\begin{abstract}
This report was prepared as an account of work sponsored by an agency of the United States Government. Neither the United States Government nor any agency thereof, nor any of their employees, makes any warranty, express or implied, or assumes any legal liability or responsibility for the accuracy, completeness, or usefulness of any information, apparatus, product, or process disclosed, or represents that its use would not infringe privately owned rights. Reference herein to any specific commercial product; process, or service by trade name, trademark, manufacturer, or otherwise does not necessarily constitute or imply its endorsement, recommendation, or favoring by the United States Government or any agency thereof. The views and opinions of authors expressed herein do not necessarily state or reflect those of the United States Government or any agency thereof.
\end{abstract}

\section{Prepared in cooperation with the U.S. DEPARTMENT OF ENERGY}

Idaho Falls, Idaho

August 1994 


\section{U.S. DEPARTMENT OF THE INTERIOR \\ BRUCE BABBITT, Secretary \\ U.S. GEOLOGICAL SURVEY \\ Gordon P. Eaton, Director}

For additional information write to:

Project Chief

U.S. Geological Survey

INEL, MS 4148

P.O. Box 2230

Idaho Falls, ID 83403
Copies of this report can be purchased from:

U.S. Geological Survey

Earth Science Information Center

Open-File Reports Section

Box 25286, MS 517

Denver Federal Center

Denver, CO 80225 


\section{DISCLAMMIER}

Portions of this document may be illegible in electronic image products. Images are produced from the best available original document. 


\section{CONTENTS}

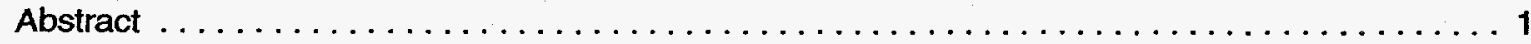

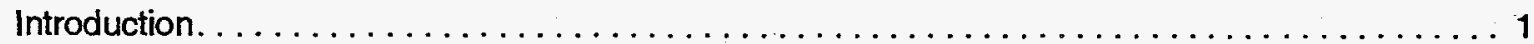

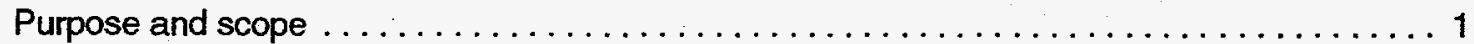

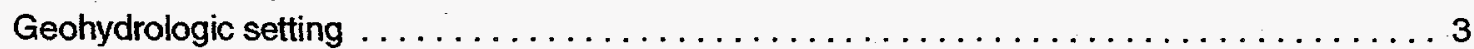

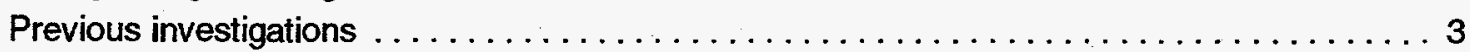

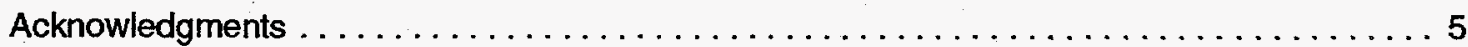

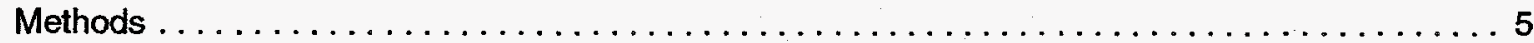

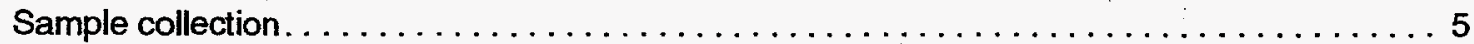

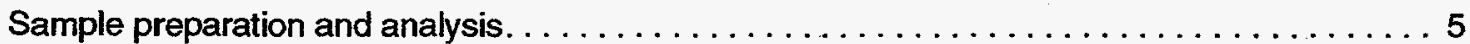

Mineralogy of selected sedimentary interbeds $\ldots \ldots \ldots \ldots \ldots \ldots \ldots \ldots \ldots \ldots \ldots, \ldots \ldots$

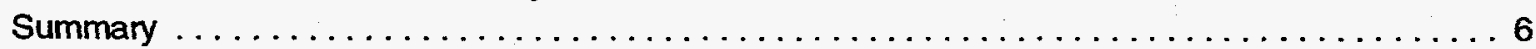

References cited. . . . . . . . . . . . . . . . . . . . . . . . . 7

\section{FIGURES}

1. Map showing location of the Idaho National Engineering Laboratory $\ldots \ldots \ldots \ldots \ldots \ldots . \ldots 2$

2. Map showing location of core hole sites at the Idaho National Engineering Laboratory $\ldots \ldots \ldots 4$

\section{TABLES}

1. Bulk mineralogy of samples by $X$-ray diffraction analysis from sedimentary interbeds at the Idaho National Engineering Laboratory. . . . . . . . . . . . . . . . . . . . . 9

2. Statistical parameters for bulk mineralogy of sedimentary interbeds by hydrologic basin $\ldots \ldots 13$

3. Statistical parameters for bulk mineralogy of sedimentary interbeds in the vicinity of selected facilities at the Idaho National Engineering Laboratory. . . . . . . . . 14

4. Mineralogy of particle fraction less than 2 micrometers by $X$-ray diffraction analysis of samples from selected sedimentary interbeds at the ldaho National Engineering Laboratory ... 16

5. Clay mineralogy of sediment and vesicle infill by $X$-ray diffraction analysis of core samples

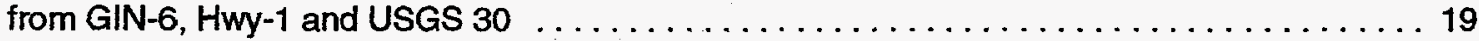

CONVERSION FACTORS AND VERTICAL DATUM

\begin{tabular}{rcl}
\hline Multiply & By & To Obtain \\
\hline acre-foot (acre-ft) & 1,233 & cubic meter \\
foot (ft) & 0.3048 & meter \\
inch (in.) & 25.4 & millimeter \\
mile (mi) & 1.609 & kilometer \\
square mile (mi $\left.\mathbf{m}^{2}\right)$ & 2.590 & square kilometer \\
\hline
\end{tabular}

Sea level: In this report, "sea level" refers to the National Geodetic Vertical Datum of 1929-a geodetic datum derived from a general adjustment of the first-order level nets of the United States and Canada, formerly called Sea Level Datum of 1929. 


\title{
Mineralogy of Selected Sedimentary Interbeds at or near the Idaho National Engineering Laboratory,
}

\section{Idaho}

\author{
By Michael F. Reed and Roy C. Bartholomay
}

\begin{abstract}
The U.S. Geological Survey's (USGS) Project Office at the Idaho National Engineering Laboratory (INEL), in cooperation with the U.S. Department of Energy and Idaho State University, analyzed 66 samples from sedimentary interbed cores during a 38-month period beginning in October 1990 to determine bulk and clay mineralogy. These cores had been collected from 19 sites in the Big Lost River Basin, 2 sites in the Birch Creek Basin, and 1 site in the Mud Lake Basin, and were archived at the USGS lithologic core library at the INEL.

Mineralogy data indicate that core samples from the Big Lost River Basin have larger mean and median percentages of quartz, total feldspar, and total clay minerals, but smaller mean and median percentages of calcite than the core samples from the Birch Creek Basin. Core samples from the Mud Lake Basin have abundant quartz, total feldspar, calcite, and total clay minerals.
\end{abstract}

\section{INTRODUCTION}

The Idaho National Engineering Laboratory (INEL), which encompasses about $890 \mathrm{mi}^{2}$ of the eastem Snake River Plain in southeastem Idaho (fig. 1), is operated by the U.S. Department of Energy (DOE). INEL facilities are used in the development of peacetime atomic-energy applications, nuclear safety research, defense programs, and advanced energy concepts. Liquid radionuclide and chemical wastes generated at these facilities have been discharged to onsite infiltration ponds and disposal wells since 1952. Many of the waste constituents enter the Snake River Plain aquifer indirectly following percolation through the unsaturated zone (Pittman and others, 1988, p. 2); however, the movement of some constituents-including some radionuclides-may be retarded by minerals in the unsaturated zone.

In 1949, the U.S. Atomic Energy Commission-now the U.S. DOE-requested that the U.S. Geological Survey (USGS) investigate the geohydrologic conditions at the INEL and adjacent areas before the development of reactor operations. Ongoing research by the USGS at the INEL involves investigation of the migration of radioactive elements contained in low-level radioactive waste, hydrologic and geologic factors affecting waste movement, and geochemical factors that influence the chemical composition of the waste. Identification of the mineralogy of the Snake River Plain is needed to aid in the study of the hydrology and geochemistry of subsurface waste disposal.

\section{Purpose and Scope}

This report describes the methods used to collect, prepare, and analyze 66 sedimentary interbed core samples from 22 sites: 19 in the Big Lost River Basin, 2 in the Birch Creek Basin, and 1 in the Mud Lake Basin (fig. 2). The samples were collected from selected cores archived at the USGS lithologic core library at the INEL. Samples were analyzed for bulk and clay mineralogy by the USGS, in cooperation with the DOE and Idaho State University (ISU), during a 38-month period 


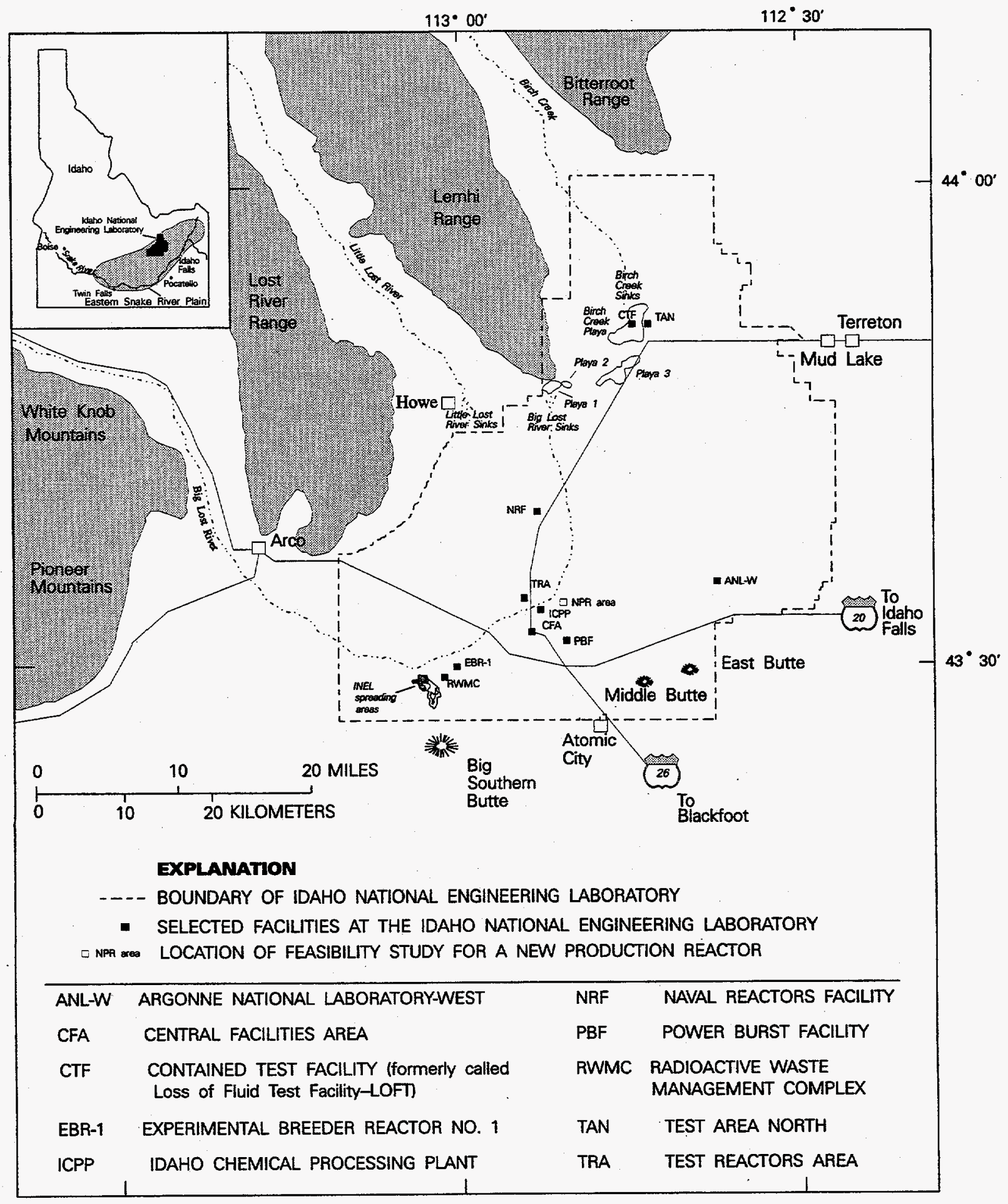

Figure 1.--Location of the Idaho National Engineering Laboratory. 
beginning in October 1990 . In addition, clay mineralogy analyses of 10 samples from 3 sites analyzed in 1970 are presented because the data have not been published previously.

\section{Geohydrologic Setting}

The eastern Snake River Plain is a northeasttrending structural basin about $200 \mathrm{mi}$ long and 50 to $70 \mathrm{mi}$ wide (fig. 1). The plain is underlain by a layered sequence of basaltic lava flows and cinder beds interbedded with eolian, fluvial, and lacustrine sedimentary deposits. Thickness of individual flows generally ranges from 10 to $50 \mathrm{ft}$ and the average thickness may be from 20 to $25 \mathrm{ft}$ (Mundorff and others, 1964, p. 143). The sedimentary deposits consist mainly of beds of sand, silt, and clay with lesser amounts of gravel. Locally, hyolitic lava flows and tuffs are exposed at land surface or occur at depth. The basaltic lava flows and interbedded sedimentary deposits. combine to form the Snake River Plain aquifer, which is the main source of water on the plain. The altitude of the water table for the Snake River Plain aquifer in July 1988 ranged from about $4,590 \mathrm{ft}$ above sea level in the northern part of the INEL to about $4,420 \mathrm{ft}$ in the southern part (Orr and Cecil, 1991, p. 25). Corresponding depths to water below land surface ranged from about $200 \mathrm{ft}$ in the northern part of the INEL to more than $900 \mathrm{ft}$ in the southeastem part (Orr and Cecil, 1991, p. 25). The INEL obtains its entire water supply from the Snake River Plain aquifer.

Much of the northern part of the INEL is a topographically closed depression that includes the Big Lost River Sinks; Little Lost River Sinks; Birch Creek Sinks; Big Lost River Playas 1, 2, and 3; and Birch Creek Playa. The Big Lost River, Little Lost River, and Birch Creek terminate in the Birch Creek Playa (Robertson and others, 1974, p. 8) (fig. 1). The INEL also contains several other small, isolated closed basins. Flow from the Little Lost River and Birch Creek is diverted for irrigation and power generation and does not reach the playas except during years with above-normal flow. Surface water at the INEL principally is derived from flow in the Big Lost River, most of which ultimately recharges the Snake River Plain aquifer. Data from May and November 1985 seepage runs on the Big Lost River near the Idaho Chemical Processing Plant (ICPP) (fig. 1) indicate that the river loses from 1.1 to 3.8 (acre-ft/day)/mi depending on the amount of flow in the channel (Mann and others, 1988, p. 17). Other surface drainages that provide recharge to the Snake River Plain aquifer at the INEL include Birch Creek, the Little Lost River, and streams terminating in Mud Lake (fig. 2).

\section{Previous Investigations}

The USGS has conducted geologic, hydrologic, and water-quality investigations at the INEL since it was selected as a reactor testing area in 1949. Many reports generated by these investigations contain data on the physical and chemical characteristics of the Snake River Plain aquifer materials. Information published in previous USGS reports, including the type of data and the number of analyses for each, are summarized in Bartholomay and others (1989).

Mineralogic data for surficial sediment or sedimentary interbeds are presented in several reports. Mineralogical data for silt and clay-sized material from several shallow core holes at the INEL were presented by Voegeli and Deutsch (1953) and Nace and others (1956). The data published by Nace and others (1956) were republished by Nace and others (1975). Mineralogical data for surficial sediment from the Big Lost River drainage basin were presented by Bartholomay and others $(1989$, table 8 , p. 23). Mineralogic data for surficial sediment from the Little Lost River and Birch Creek drainage basins were presented by Bartholomay and Knobel (1989, tables 4-5, p. 17-18). Mineralogical data for sedimentary interbeds at the Radioactive Waste Management Complex (RWMC), Test Reactors Area (TRA), and ICPP were presented by Barraclough and others (1976, table A-V, p. 123-124); Rightmire (1984, table 5, p. 17); Rightmire and Lewis (1987, table 7, p. 35); and Bartholomay and others (1989, table 11, p. 30). Mineralogical data for a sedimentary interbed $400 \mathrm{ft}$ below land surface at Test Area North (TAN) were presented in Bartholomay (1990, table 2, p. 9). 


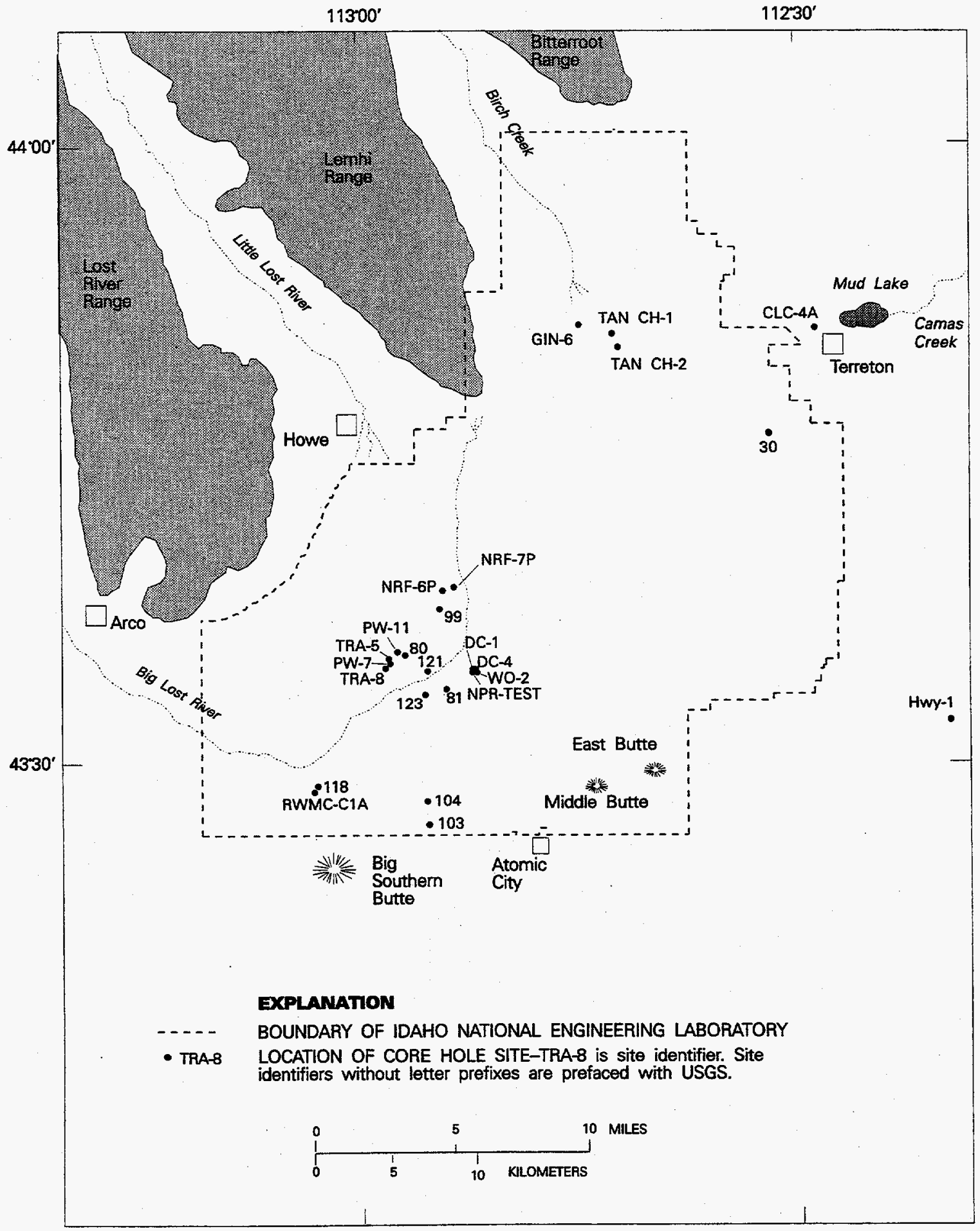

Figure 2.-Location of core hole sites at the Idaho National Engineering Laboratory. 


\section{Acknowledgments}

The authors gratefully acknowledge the ISU Department of Geology-David W. Rodgers, Chairman-for providing X-ray diffraction equipment, laboratory space, and computer support. In addition, special thanks are given to Jeanne Fromm of the ISU Department of Geology for information on well USGS 123 and Judith Krieg of the ISU Department of Geology for her help with the clay-separation techniques. The authors are grateful for technical review of the manuscript by Judith Krieg of ISU and LeRoy L. Knobel of the USGS.

\section{METHODS}

\section{Sample Collection}

Samples collected from archived sedimentary interbed cores from 22 sites were analyzed during a 38-month period beginning in October 1990 (fig. 2). The basis for selection was the availability of core at the USGS lithologic core library at the INEL. Sediments from 19 sites in the Big Lost River Basin were sampled as follows: 14 samples from 4 sites (DC-1, DC-4, NPR-TEST, and WO-2) at the New Production Reactor (NPR) area; 10 samples from 5 sites (PW-7, PW-11, TRA-5, TRA-8, and USGS 80) near the TRA; 13 samples from 3 sites (USGS 81, USGS121, and USGS 123) near the ICPP; 8 samples from 2 sites (RWMCC1A and USGS 118) near the RWMC; 5 samples from 3 sites (NRF-6P, NRF-7P, and USGS 99) near the Naval Reactors Facility (NRF); 1 sample from USGS 103; and 1 sample from USGS 104. In addition, nine sediment cores from two sites (TAN CH-1 and TAN CH-2) near TAN in the Birch Creek Basin, and five sediment cores from one site (CLC-4A) in the Mud Lake Basin also were sampled. Samples were collected by placing approximately 20 grams (g) of sediment from a drill core into a glass container. The samples were labeled and transported to the ISU laboratory for analyses.

In addition, clay mineralogy of 10 samples that were analyzed in 1970 is presented because these data have not been published previously. The 10 samples were from sites GIN-6, Hwy-1, and USGS 30 and consisted of sediment and vesicle infill.

\section{Sample Preparation and Analysis}

$\mathrm{X}$-ray diffraction analysis was used to determine bulk mineralogy of all particles less than 0.5 millimeters $(\mathrm{mm})$ in diameter and clay mineralogy of particles less than 2 micrometers $(\mu \mathrm{m})$ in diameter. Clay mineralogy was determined only for samples that had clay minerals present in the bulk analysis. To determine bulk mineralogy, the sample first was passed through a 0.5 -mm sieve, then approximately $3 \mathrm{~g}$ was ground for 8 minutes in a ball-and-mill device to reduce grain size and to homogenize the sample. The sample then was ground using a mortar and pestle until all of the sample passed through a $0.062-\mathrm{mm}$ sieve. The powdered sample was packed into an aluminum holder and scanned with a diffractometer using copper $\mathrm{K} \alpha$ (wavelength of the characteristic line) radiation at a rotation rate of 1 degree 2 theta per minute. The generator was operated at 35 kilovolts and 15 milliamps.

Diffractograms were prepared at a scale factor of 1 , a multiplier of 0.5 , a time constant of 2 , and a chart speed of 2 degrees 2 theta per inch.

Semiquantitative analysis was used to determine the relative abundances of minerals in the samples. To obtain the relative mineral percentages, a modification of the method described by Diebold and others (1963) and Schultz (1964) was used. The raw percentage of each mineral was determined by dividing the intensity of each mineral peak height by the intensity of its pure standard. The raw percentages were normalized to 100 percent. The intensities of the pure standards were calculated from standard minerals provided by the ISU Department of Geology. Schultz (1964, p. C1) reported uncertainties of \pm 10 percent for minerals that make up at least 15 percent of the sample. Diebold and others (1963, table 5, p. 130) calculated weight percentages within \pm 8 percent of the true concentrations using a 95-percent confidence interval.

For samples that had a total clay mineral peak present in the bulk mineralogy analysis, a qualitative identification of individual clay minerals was made. A modification of methods described by 
Drever (1973), Jackson (1985), and Kunze (1965) was used to prepare clay slides for analysis. First, the organic matter was removed from approximately $5 \mathrm{~g}$ of the original sample by using a solution containing 30 percent hydrogen peroxide. Next, sodium hexametaphosphate was added to aid in the dispersing of the clay particles. The less-than-45- $\mu \mathrm{m}$ fraction then was isolated by using a 325-mesh sieve. The less-than- $2-\mu \mathrm{m}$ clay particle fraction was isolated by using the principle of Stoke's Law, which predicts that the finest siltsize particles will settle below the top 5 centimeters of suspension after 3.5 hours. After 3.5 hours, the suspended clay particles were collected by pipette and concentrated on a $0.45 \mu \mathrm{m}$ filter. The filtrate was then transferred to a glass slide and allowed to dry. Once the sample was dry, it was scanned by $\mathrm{X}$-ray diffraction to determine the clay minerals present.

The slides were scanned with a diffractometer using copper $\mathrm{K} \alpha$ radiation at a rotation rate of 1 degree 2 theta per minute. The generator was operated at 35 kilovolts and 15 milliamps.

Diffractograms were prepared at a scale factor of 1 or 0.5 , a multiplier of 0.5 , and a time constant of 2 .

The samples were exposed to ethylene glycol for at least 24 hours and rescanned to differentiate between smectite and chlorite clays. Smectite expands from 14 to 17 angstrom units when ethylene glycol replaces water in the crystal lattice.

The results reported by the $\mathrm{X}$-ray diffraction laboratory at ISU for the 49 samples analyzed for clay mineralogy give qualitative estimates of the abundance of clay minerals in the samples. The estimates were based on the relative heights of the clay mineral peaks on the X-ray diffractograms. Six categories were designated in order of decreasing abundance: dominant, major, minor, trace, possibly present, and not detected

\section{Mineralogy of Selected Sedimentary Interbeds}

The bulk mineralogy of 66 samples from 22 sites is listed in table 1 as percent mineral abundance. Statistical parameters for the bulk mineralogy data are listed by hydrologic basin in table 2 , and by selected facility in table 3 . Clay mineralogy for 49 of the 66 samples is listed in table 4. X-ray slides were not prepared for 17 of the samples because they did not contain clay minerals. Clay mineralogy for 10 samples from 3 sites analyzed in 1970 is listed in table 5.

Statistical parameters for semiquantitative bulk mineral analyses for sedimentary interbeds (table 2) show that quartz, total feldspar, and total clay minerals are abundant in core samples from the Big Lost River Basin. Fifty-two core samples from the Big Lost River Basin have respective mean and median percentages of 36 and 36 for quartz; 29 and 29 for total feldspar, and 15 and 14 for total clay minerals. Samples collected in the vicinity of selected facilities, which are all in the Big Lost River Basin, have similar abundances of quartz, total feldspar, and total clay minerals (table 3 ).

Core samples from the Birch Creek Basin have less abundant quartz, total feldspar, and total clay minerals than core samples from the Big Lost River Basin. Respective mean and median percentages for the Birch Creek Basin are 21 and 20 for quartz, 8 and 8 for total feldspar, and 6 and 4 for total clay minerals.

Overall, calcite is not abundant in core samples from the Big Lost River Basin but is abundant in samples from the Birch Creek Basin (table 2). For example, the respective mean and median percentages of calcite for the Big Lost River Basin are 12 and 5.5; conversely, the respective mean and median percentages of calcite for the Birch Creek Basin are 62 and 72.

Core samples from site CLC-4A in the Mud Lake Basin (fig. 2) have respective mean and median percentages of 31 and 33 for quartz; 19 and 17 for total feldspar, 22 and 15 for calcite; and 21 and 22 for total clay minerals (table 2 ).

Clay mineral analyses of the 49 samples containing clay minerals show that smectite and illite are the most abundant clay minerals (table 4). Clay mineral analyses of the eight sediment samples and two vesicle infill samples analyzed in 1970 show that smectite is the most abundant clay mineral (table 5).

\section{SUMMARY}

The USGS project office at the INEL, in cooperation with the DOE and ISU, analyzed 66 samples from archived sedimentary interbed cores 
from 22 sites during a 38-month period beginning October 1990 to determine bulk and clay mineralogy. The cores had been collected from 19 sites in the Big Lost River Basin, 2 sites in the Birch Creek Basin, and 1 site in the Mud Lake Basin.

Semiquantitative $\mathrm{X}$-ray diffraction analysis was used to determine bulk mineralogy. Individual clay minerals were identified in 49 samples.

Mineralogy data indicate that the core samples from the Big Lost River Basin have larger mean and median percentages of quartz, total feldspar, and total clay minerals, but simaller mean and median percentages of calcite than core samples from the Birch Creek Basin. Core samples from the Mud Lake Basin have abundant quartz, total feldspar, calcite, and total clay minerals. Smectite and illite are the most abundant clay minerals present.

Clay mineral analyses of eight sediment samples and two vesicle infill samples analyzed in 1970 show that smectite is most abundant mineral.

\section{REFERENCES CITED}

Barraclough, J.T., Robertson, J.B., and Janzer, V.J., 1976, Hydrology of the solid waste burial ground, as related to the potential migration of radionuclides, Idaho National Engineering Laboratory, with a section on Drilling and sample analysis, by L.G. Saindon: U.S. Geological Survey Open-File Report 76-471 (IDO-22056), 183 p.

Bartholomay, R.C., 1990, Mineralogical correlation of surficial sediment from area drainages with selected sedimentary interbeds at the Idaho National Engineering Laboratory, Idaho: U.S. Geological Survey Water-Resources Investigations Report 90-4147 (DOE/ID-22092), $18 \mathrm{p}$.

Bartholomay, R.C., and Knobel, L.L., 1989, Mineralogy and grain size of surficial sediment from the Little Lost River and Birch Creek drainages, Idaho National Engineering Laboratory, Idaho: U.S. Geological Survey Open-File Report 89-385 (DOE/ID-22082), 19 p.
Bartholomay, R.C., Knobel, L.L., and Davis, L.C., 1989, Mineralogy and grain size of surficial sediment from the Big Lost River drainage and vicinity, with chemical and physical characteristics of geologic materials from selected sites at the Idaho National Engineering Laboratory, Idaho: U.S. Geological Survey Open-File Report 89-384 (DOE/ID-22081), 74 p.

Diebold, F.E., Lemish, John, and Hiltrop, C.L., 1963, Determination of calcite, dolomite, quartz, and clay content of carbonate rocks: Journal of Sedimentary Petrology, v. 33, no. 1, p. 124-139.

Drever, J.I., 1973, The preparation of oriented clay mineral specimens for X-ray diffraction analysis by a filter-membrane peel technique: American Mineralogist, v. 58, p. 553-554.

Jackson, M.L., 1985, Soil chemical analysis-advanced course, 2nd edition, 11th printing: published by the author, Madison, Wis. 53705, 895 p.

Kunze, G.W., 1965, Pretreatment for mineralogical analysis, in Black, C.A., and others, eds., Methods for soil analysis, part 1: Agronomy, v. 9, p. 569-571.

Mann, LJ., Chew, E.W., Morton, J.S., and Randolph, R.B., 1988, Iodine-129 in the Snake River Plain aquifer at the Idaho National Engineering Laboratory, Idaho: U.S. Geological Survey Water-Resources Investigations Report 88-4165 (DOE/ID-22076), $27 \mathrm{p}$.

Mundorff, M.J., Crosthwaite, E.G., and Kilburn, Chabot, 1964, Ground water for irrigation in the Snake River Basin in Idaho: U.S. Geological Survey Water-Supply Paper 1654, 224 p.

Nace, R.L., Deutsch, Morris, and Voegeli, P.T., 1956, Geography, geology, and water resources of the National Reactor Testing Station, Idaho, part 2, geography and geology: U.S. Atomic Energy Commission Publication IDO-22033, 225 p.

Nace, R.L., Voegeli, P.T., Jones, J.R., and Deutsch, Morris, 1975, Generalized geologic framework of the National Reactor Testing Station, Idaho: U.S. Geological Survey Professional Paper 725-B, 49 p.

Or, B.R., and Cecil, L.D., 1991, Hydrologic conditions and distribution of selected chemical constituents in water, Snake River Plain aquifer, Idaho National Engineering Laboratory, Idaho, 1986 to 1988: U.S. Geological Survey Water-Resources Investigations Report 91-4047 (DOE/DD-22096), $56 \mathrm{p}$. 
Pittman, J.R., Jensen, R.J., and Fischer, P.R., 1988, Hydrologic conditions at the Idaho National Engineering Laboratory, 1982 to 1985: U.S. Geological Survey Water-Resources Investigations Report 89-4008 (DOE/ID-22078), $73 \mathrm{p}$.

Rightmire, C.T., 1984, Description and hydrogeologic implications of cored sedimentary material from the 1975 drilling program at the Radioactive Waste Management Complex, Idaho: U.S. Geological Survey Water-Resources Investigations Report 84-4071 (DOE/ID-22067), 33 p.

Rightmire, C.T., and Lewis, B.D., 1987, Geologic data collected and analytical procedures used during a geochemical investigation of the unsaturated zone, Radioactive Waste Management Complex, Idaho National Engineering Laboratory, Idaho: U.S. Geological Survey Open-File Report 87-246 (DOE/ID-22072), $83 \mathrm{p}$.

Robertson, J.B., Schoen, Robert, and Barraclough, J.T., 1974 , The influence of liquid waste disposal on the geochemistry of water at the National Reactor Testing Station, Idaho: U.S. Geological Survey Open-File Report 73-238 (IDO-22053), 231 p.

Schultz, L.G., 1964, Quantitative interpretation of mineralogical composition from X-ray and chemical data for the Pierre Shale: U.S. Geological Survey Professional Paper 391-C, 33 p.

Voegeli, P.T., and Deutsch, Morris, 1953, Geology, water supply, and waste disposal at Sites 11 and $11 \mathrm{~A}$, burial ground $\mathrm{D}$, and vicinity, National Reactor Testing Station, Idaho: U.S. Atomic Energy Commission Publication IDO-22027, 42 p. 
Table 1.-Bulk mineralogy of samples by X-ray diffraction analysis from selected sedimentary interbeds at the Idaho National Engineering Laboratory

[See figure 2 for location of core-hole sites. Samples analyzed at the X-ray diffraction laboratory at Idaho State University]

\begin{tabular}{|c|c|c|c|c|c|c|c|c|c|c|c|}
\hline \multirow[b]{2}{*}{$\begin{array}{c}\text { Site } \\
\text { identifier }\end{array}$} & \multirow[b]{2}{*}{$\begin{array}{c}\text { Date } \\
\text { sampled }\end{array}$} & \multirow{2}{*}{$\begin{array}{c}\text { Interval sampled } \\
\text { (feet below } \\
\text { land surface) }\end{array}$} & \multicolumn{9}{|c|}{ Bulk analyses (in percent mineral abundance) } \\
\hline & & & Quartz & $\begin{array}{l}\text { Plagioclase } \\
\text { feldspar }\end{array}$ & $\begin{array}{l}\text { Potassium } \\
\text { feldspar }\end{array}$ & Calcite & Pyroxene & Olivine & Dolomite & Hematite & $\begin{array}{r}\text { Total clay } \\
\text { minerals }\end{array}$ \\
\hline \multicolumn{12}{|c|}{ [Big Lost River Basin] } \\
\hline DC-1 & $2 / 24 / 93$ & 238 & 44 & 26 & 5 & 15 & 0 & 0 & 0 & 0 & 10 \\
\hline DC-4 & $2 / 24 / 93$ & $112.9-113.3$ & 15 & 9 & 13 & 52 & 0 & 0 & 0 & 0 & 11 \\
\hline DC-4 & $2 / 24 / 93$ & 241.7 & 33 & 23 & 5 & 15 & 0 & 0 & 0 & 0 & 25 \\
\hline NPR-TEST & $11 / 13 / 90$ & $100-112$ & 29 & 18 & 12 & 31 & 0 & 0 & 0 & 0 & 10 \\
\hline NPR-TEST & $11 / 13 / 90$ & $247-265$ & 32 & 16 & 10 & 3 & 8 & 0 & 0 & 0 & 31 \\
\hline NPR-TEST & $11 / 13 / 90$ & 410 & 38 & 15 & 10 & 0 & 10 & 0 & 0 & 0 & 26 \\
\hline NPR-TEST & $11 / 13 / 90$ & $413-425$ & 32 & 16 & 6 & 0 & 9 & 0 & 0 & 0 & 36 \\
\hline WO-2 & $2 / 24 / 93$ & $560-564$ & 62 & 19 & 19 & 0 & 0 & 0 & 0 & 0 & 0 \\
\hline WO-2 & $2 / 24 / 93$ & 600 & 21 & 15 & 15 & 6 & 0 & 0 & 0 & 0 & 42 \\
\hline WO-2 & $2 / 24 / 93$ & 719 & 39 & 13 & 18 & 3 & 0 & 0 & 1 & 0 & 26 \\
\hline WO-2 & $2 / 24 / 93$ & 815 & 30 & 25 & 6 & 8 & 6 & 6 & 0 & 0 & 20 \\
\hline WO-2 & $2 / 24 / 93$ & 871 & 34 & 9 & 5 & 36 & 0 & 0 & 0 & 0 & 16 \\
\hline WO-2 & $2 / 24 / 93$ & 932.3 & 32 & 27 & 18 & 2 & 11 & 0 & 1 & 0 & 8 \\
\hline WO-2 & $2 / 24 / 93$ & 1001.5 & 31 & 20 & 13 & 1 & 8 & 0 & 0 & 0 & 28 \\
\hline PW-7 & $6 / 9 / 93$ & 219.3 & 45 & 17 & 0 & 0 & 0 & 0 & 0 & 0 & 38 \\
\hline PW-7 & $6 / 9 / 93$ & 230 & 44 & 19 & 14 & 3 & 6 & 0 & 0 & 0 & 13 \\
\hline PW-11 & $6 / 9 / 93$ & 139.4 & 26 & 12 & 10 & 6 & 46 & 0 & 0 & 0 & 0 \\
\hline TRA-5 & $6 / 9 / 93$ & 69 & 31 & 6 & 0 & 13 & 6 & 0 & 0 & 0 & 43 \\
\hline TRA-5 & $6 / 9 / 93$ & 150 & 2 & 2 & 0 & 96 & 0 & 0 & 0 & 0 & 0 \\
\hline
\end{tabular}


Table 1.-Bulk mineralogy of samples by X-ray diffraction analysis from selected sedimentary interbeds at the Idaho National Engineering Laboratory-Continued

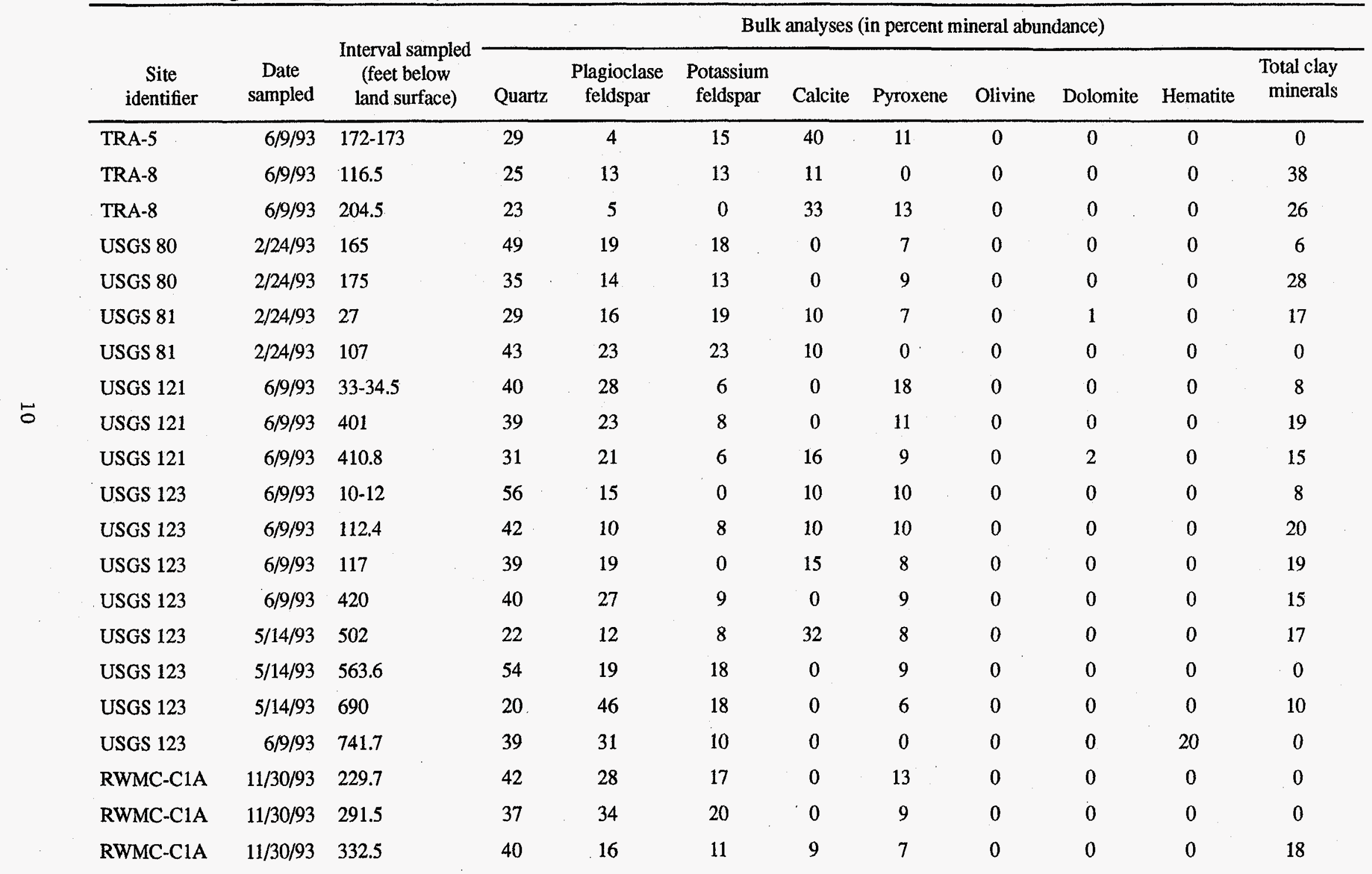


Table 1.-Bulk mineralogy of samples by X-ray diffraction analysis from selected sedimentary interbeds at the Idaho National Engineering Laboratory-Continued

\begin{tabular}{|c|c|c|c|c|c|c|c|c|c|c|c|}
\hline \multirow[b]{2}{*}{$\begin{array}{c}\text { Site } \\
\text { identifier }\end{array}$} & \multirow[b]{2}{*}{$\begin{array}{c}\text { Date } \\
\text { sampled }\end{array}$} & \multirow[b]{2}{*}{$\begin{array}{l}\text { Interval sampled } \\
\text { (feet below } \\
\text { land surface) }\end{array}$} & \multicolumn{9}{|c|}{ Bulk analyses (in percent mineral abundance) } \\
\hline & & & Quartz & $\begin{array}{l}\text { Plagioclase } \\
\text { feldspar }\end{array}$ & $\begin{array}{l}\text { Potassium } \\
\text { feldspar }\end{array}$ & Calcite & Pyroxene & Olivine & Dolomite & Hematite & $\begin{array}{r}\text { Total clay } \\
\text { minerals }\end{array}$ \\
\hline RWMC-C1A & $11 / 30 / 93$ & 745.7 & 39 & 20 & 15 & 0 & 12 & 0 & 0 & 0 & 14 \\
\hline RWMC-C1A & $11 / 30 / 93$ & 971 & 35 & 12 & 0 & 24 & 0 & 0 & 0 & 0 & 29 \\
\hline RWIMC-CiA & $11 / 30 / 93$ & $1,072.3$ & 39 & 16 & 11 & 0 & 11 & 0 & 0 & 0 & 23 \\
\hline USGS 118 & $2 / 24 / 93$ & 9.4 & 44 & 25 & 13 & 0 & 4 & 0 & 0 & 0 & 14 \\
\hline USGS 118 & $6 / 9 / 93$ & 237.9 & 39 & 11 & 16 & 16 & 6 & 0 & 0 & 0 & 13 \\
\hline NRF-6P & $6 / 9 / 93$ & 94.8 & 31 & 13 & 11 & 30 & 11 & 0 & 3 & 0 & 0 \\
\hline NRF-6P & $6 / 9 / 93$ & 354 & 36 & 27 & 20 & 0 & 16 & 0 & 0 & 0 & 0 \\
\hline NRF-7P & $6 / 9 / 93$ & 93 & 36 & 25 & 22 & 0 & 8 & 0 & 0 & 0 & 9 \\
\hline NRF-7P & $6 / 9 / 93$ & 156 & 15 & 9. & 0 & 75 & 0 & 0 & 0 & 0 & 0 \\
\hline USGS 99 & $2 / 24 / 93$ & $25-30$ & 43 & 19 & 18 & 6 & 4 & 0 & 0 & 0 & 10 \\
\hline USGS 103 & $2 / 24 / 93$ & 15 & 36 & 17 & 13 & 4 & 12 & 0 & 0 & 0 & 17 \\
\hline USGS 104 & $2 / 24 / 93$ & 142 & 64 & 28 & 0 & 5 & 3 & 0 & 0 & 0 & 0 \\
\hline \multicolumn{12}{|c|}{ [Birch Creek Basin] } \\
\hline TAN CH-1 & $6 / 9 / 93$ & 401 & 20 & 0 & 0 & 80 & 0 & 0 & 0 & 0 & 0 \\
\hline TAN CH-1 & $6 / 9 / 93$ & 411 & 11 & 4 & 4 & 82 & 0 & 0 & 0 & 0 & 0 \\
\hline TAN CH-1 & $6 / 9 / 93$ & 444.5 & 8 & 2 & 0 & 81 & 0 & 0 & 0 & 0 & 8 \\
\hline TAN CH-1 & $6 / 9 / 93$ & 446.5 & 9 & 8 & 0 & 72 & 0 & 0 & 2 & 0 & 9 \\
\hline TAN CH-2 & $6 / 9 / 93$ & 245.5 & 22 & 3 & 3 & 58 & 0 & 0 & 0 & 0 & 14 \\
\hline TAN CH-2 & $6 / 9 / 93$ & 449 & 44 & 9 & 0 & 46 & 0 & 0 & 0 & 0 & 0 \\
\hline TAN CH-2 & $6 / 9 / 93$ & 471.5 & 2 & 0 & 0 & 98 & 0 & 0 & 0 & 0 & 0 \\
\hline TAN CH-2 & $6 / 9 / 93$ & 735 & 23 & 19 & 0 & 27 & 13 & 0 & 13 & 0 & 4 \\
\hline
\end{tabular}


Table 1.-Bulk mineralogy of samples by X-ray diffraction analysis from selected sedimentary interbeds at the Idaho National Engineering Laboratory-Continued

\begin{tabular}{|c|c|c|c|c|c|c|c|c|c|c|c|}
\hline \multirow[b]{2}{*}{$\begin{array}{c}\text { Site } \\
\text { identifier }\end{array}$} & \multirow[b]{2}{*}{$\begin{array}{c}\text { Date } \\
\text { sampled }\end{array}$} & \multirow{2}{*}{$\begin{array}{l}\text { Interval sampled } \\
\text { (feet below } \\
\text { land surface) }\end{array}$} & \multicolumn{9}{|c|}{ Bulk analyses (in percent mineral abundance) } \\
\hline & & & Quartz & $\begin{array}{l}\text { Plagioclase } \\
\text { feldspar }\end{array}$ & $\begin{array}{l}\text { Potassium } \\
\text { feldspar }\end{array}$ & Calcite & Pyroxene & Olivine & Dolomite & Hematite & $\begin{array}{r}\text { Total clay } \\
\text { minerals }\end{array}$ \\
\hline TAN CH-2 & $6 / 9 / 93$ & 977.7 & 47 & 13 & 11 & 10 & 0 & 0 & 0 & 0 & 19 \\
\hline \multicolumn{12}{|c|}{ [Mud Lake Basin] } \\
\hline CLC-4A & $10 / 24 / 90$ & $0-1.3$ & 35 & 14 & 7 & 15 & 7 & 0 & 0 & 0 & 22 \\
\hline CLC-4A & $10 / 24 / 90$ & $1.3-2.5$ & 21 & 8 & 5 & 35 & 0 & 0 & 4 & 0 & 26 \\
\hline CLC-4A & $10 / 24 / 90$ & $4.5-5.2$ & 24 & 10 & 5 & 31 & 0 & 0 & 6 & 0 & 24 \\
\hline CLC-4A & $10 / 24 / 90$ & $6.3-7.0$ & 42 & 12 & 5 & 14 & 9 & 0 & 5 & 0 & 13 \\
\hline CLC- $4 A$ & $10 / 24 / 90$ & $15-16$ & 33 & 19 & 12 & 13 & 0 & 0 & 2 & 0 & 21 \\
\hline
\end{tabular}


Table 2.-Statistical parameters for bulk mineralogy of sedimentary interbeds by hydrologic basin

[Values are percent mineral abundance and are derived from table 1. Total feldspar is the sum of plagioclase feldspar and potassium feldspar in table 1]

\begin{tabular}{|c|c|c|c|c|c|}
\hline \multirow[b]{2}{*}{ Mineral } & \multicolumn{5}{|c|}{ Statistical parameter } \\
\hline & Minimum & Maximum & Median & Mean & Sample size \\
\hline \multicolumn{6}{|c|}{ [Big Lost River Basin] } \\
\hline Quartz & 2 & 64 & 36 & 36 & 52 \\
\hline Plagioclase feldspar & 2 & 46 & 17.5 & 18 & 52 \\
\hline Potassium feldspar & 0 & 23 & 11 & 11 & 52 \\
\hline Total feldspar & 2 & 64 & 29 & 29 & 52 \\
\hline Calcite & 0 & 96 & 5.5 & 12 & 52 \\
\hline Pyroxene & 0 & 46 & 7.5 & 7 & 52 \\
\hline Olivine & 0 & 6 & 0 & 0 & 52 \\
\hline Dolomite & 0 & 3 & 0 & 0 & 52 \\
\hline Hematite & 0 & 20 & 0 & 0 & 52 \\
\hline Total clay minerals & 0 & 43 & 14 & 15 & 52 \\
\hline \multicolumn{6}{|c|}{ [Birch Creek Basin] } \\
\hline Quartz & 2 & 47 & 20 & 21 & 9 \\
\hline Plagioclase feldspar & 0 & 19 & 4 & 6 & 9 \\
\hline Potassium feldspar & 0 & 11 & 0 & 2 & 9 \\
\hline Total feldspar & 0 & 24 & 8 & 8 & 9 \\
\hline Calcite & 10 & 98 & 72 & 62 & 9 \\
\hline Pyroxene & 0 & 13 & 0 & 1 & 9 \\
\hline Dolomite & 0 & 13 & 0 & 2 & 9 \\
\hline Total clay minerals & 0 & 19 & 4 & 6 & 9 \\
\hline \multicolumn{6}{|c|}{ [Mud Lake Basin] } \\
\hline Quartz & 21 & 42 & 33 & 31 & 5 \\
\hline Plagioclase feldspar & 8 & 19 & 12 & 13 & 5 \\
\hline Potassium feldspar & 5 & 12 & 5 & 7 & 5 \\
\hline Total feldspar & 13 & 31 & 17 & 19 & 5 \\
\hline Calcite & 13 & 35 & 15 & 22 & 5 \\
\hline Pyroxene & 0 & 9 & 0 & 3 & 5 \\
\hline Dolomite & 0 & 6 & 4 & 3 & 5 \\
\hline Total clay minerals & 13 & 26 & 22 & 21 & 5 \\
\hline
\end{tabular}


Table 3.-Statistical parameters for bulk mineralogy of sedimentary interbeds in the vicinity of selected facilities at the Idaho National Engineering Laboratory

[Values are percent mineral abundance and are derived from table 1. New Production Reactor includes results from site identifiers DC-1, DC-4, NPR-TEST, and WO-2 (table 1). Test Reactors Area includes results from site identifiers PW-7, PW-11, TRA-5, TRA-8, and USGS 80 (table 1). Idaho Chemical Processing Plant includes results for site identifiers USGS 81, USGS 121, and USGS 123 (table 1). Radioactive Waste Management Complex includes results for site identifiers RWMC-C1A and USGS 118 (table 1). Naval Reactors Facility includes results for site identifiers NRF-6P, NRF-7P, and USGS 99 (table 1)]

\begin{tabular}{|c|c|c|c|c|c|}
\hline \multirow[b]{2}{*}{ Mineral } & \multicolumn{5}{|c|}{ Statistical parameter } \\
\hline & Minimum & Maximum & Median & Mean & Sample size \\
\hline \multicolumn{6}{|c|}{ [New Production Reactor] } \\
\hline Quartz & 15 & 62 & 32 & 34 & 14 \\
\hline Plagioclase feldspar & 9 & 27 & 17 & 18 & 14 \\
\hline Potassium feldspar & 5 & 19 & 11 & 11 & 14 \\
\hline Total feldspar & 14 & 45 & 30 & 29 & 14 \\
\hline Calcite & 0 & 52 & 4.5 & 12 & 14 \\
\hline Pyroxene & 0 & 11 & 0 & 4 & 14 \\
\hline Olivine & 0 & 6 & 0 & 0 & 14 \\
\hline Dolomite & 0 & 1 & 0 & 0 & 14 \\
\hline Total clay minerals & 0 & 42 & 22.5 & 21 & 14 \\
\hline \multicolumn{6}{|c|}{ [Test Reactors Area] } \\
\hline Quartz & 2 & 49 & 30 & 31 & 10 \\
\hline Plagioclase feldspar & 2 & 19 & 12.5 & 11 & 10 \\
\hline Potassium feldspar & 0 & 18 & 11.5 & 8 & 10 \\
\hline Total feldspar & 2 & 37 & 20.5 & 19 & 10 \\
\hline Calcite & 0 & 96 & 8.5 & 20 & 10 \\
\hline Pyroxene & 0 & 46 & 6.5 & 10 & 10 \\
\hline Total clay minerals & 0 & 43 & 19.5 & 19 & 10 \\
\hline
\end{tabular}


Table 3.-Statistical parameters for bulk mineralogy of sedimentary interbeds in the vicinity of selected facilities at the Idaho National Engineering LaboratoryContinued

\begin{tabular}{|c|c|c|c|c|c|}
\hline \multirow[b]{2}{*}{ Mineral } & \multicolumn{5}{|c|}{ Statistical parameter } \\
\hline & Minimum & Maximum & Median & Mean & Sample size \\
\hline \multicolumn{6}{|c|}{ [Idaho Chemical Processing Plant] } \\
\hline Quartz & 20 & 56 & 39 & 38 & 13 \\
\hline Plagioclase feldspar & 10 & 46 & 21 & 22 & 13 \\
\hline Potassium feldspar & 0 & 23 & 8 & 10 & 13 \\
\hline Total feldspar & 15 & 64 & 34 & 33 & 13 \\
\hline Calcite & 0 & 32 & 10 & 8 & 13 \\
\hline Pyroxene & 0 & 18 & 9 & 8 & 13 \\
\hline Dolomite & 0 & 2 & 0 & 0 & 13 \\
\hline Hematite & 0 & 20 & 0 & 2 & 13 \\
\hline Total clay minerals & 0 & 20 & 15 & 11 & 13 \\
\hline \multicolumn{6}{|c|}{ [Radioactive Waste Management Complex] } \\
\hline Quartz & 35 & 44 & 39 & 39 & 8 \\
\hline Plagioclase feldspar & 11 & 34 & 18 & 20 & 8 \\
\hline Potassium feldspar & 0 & 20 & 14 & 13 & 8 \\
\hline Total feldspar & 12 & 54 & 31 & 33 & 8 \\
\hline Calcite & 0 & 24 & 0 & 6 & 8 \\
\hline Pyroxene & 0 & 13 & 8 & 8 & 8 \\
\hline Total clay minerals & 0 & 29 & 14 & 14 & 8 \\
\hline \multicolumn{6}{|c|}{ [Naval Reactors Facility] } \\
\hline Quartz & 15 & 43 & 36 & 32 & 5 \\
\hline Plagioclase feldspar & 9 & 27 & 19 & 19 & 5 \\
\hline Potassium feldspar & 0 & 22 & 18 & 14 & 5 \\
\hline Total feldspar & 9 & 47 & 37 & 33 & 5 \\
\hline Calcite & 0 & 75 & 6 & 22 & 5 \\
\hline Pyroxene & 0 & 16 & 8 & 8 & 5 \\
\hline Dolomite & 0 & 3 & 0 & 1 & 5 \\
\hline Total clay minerals & 0 & 10 & 0 & 4 & 5 \\
\hline
\end{tabular}


Table 4.-Mineralogy of particle fraction less than 2 micrometers by X-ray diffraction analysis of samples from selected sedimentary interbeds at the Idaho National Engineering Laboratory

[See figure 2 for location of core-hole sites. Samples analyzed at the X-ray diffraction laboratory at Idaho State University. Clay analyses: tr, mineral is present in a trace amount; maj, mineral is major in abundance; min, mineral is minor in abundance; poss, mineral is possibly present; nd, not detected; dom, mineral is dominant in abundance]

\begin{tabular}{|c|c|c|c|c|c|c|c|c|c|c|c|}
\hline \multirow{3}{*}{$\begin{array}{c}\text { Site } \\
\text { identifier }\end{array}$} & \multirow{3}{*}{$\begin{array}{c}\text { Date } \\
\text { sampled }\end{array}$} & \multirow{3}{*}{$\begin{array}{l}\text { Interval sampled } \\
\text { (feet below } \\
\text { land surface) }\end{array}$} & \multicolumn{9}{|c|}{ Clay analyses (by abundance category) } \\
\hline & & & \multirow{2}{*}{$\begin{array}{l}\text { Mixed } \\
\text { layer }\end{array}$} & \multirow[b]{2}{*}{ Smectite } & \multirow[b]{2}{*}{ Kaolinite } & \multirow[b]{2}{*}{ Illite } & \multirow[b]{2}{*}{ Chlorite } & \multicolumn{4}{|c|}{ Other minerals } \\
\hline & & & & & & & & Quartz & Calcite & Feldspar & Dolomite \\
\hline DC-1 & $2 / 24 / 93$ & 238 & tr & maj & $\min$ & maj & poss & $\min$ & nd & $\operatorname{tr}$ & nd \\
\hline DC-4 & $2 / 24 / 93$ & $112.9-113.3$ & nd & nd & $\operatorname{tr}$ & $\min$ & nd & $\min$ & dom & poss & nd \\
\hline DC-4 & $2 / 24 / 93$ & 241.7 & nd & dom & $\min$ & dom & nd & $\min$ & nd & $\operatorname{tr}$ & nd \\
\hline NPR-TEST & $11 / 13 / 90$ & $100-112$ & nd & nd & nd & maj & nd & maj & maj & $\min$ & nd \\
\hline NPR-TEST & $11 / 13 / 90$ & $247-265$ & maj & dom & $\min$ & maj & $\min$ & $\min$ & nd & nd & nd \\
\hline NPR-TEST & $11 / 13 / 90$ & 410 & maj & dom & maj & dom & poss & $\min$ & nd & tr & nd \\
\hline NPR-TEST & $11 / 13 / 90$ & $413-425$ & maj & dom & maj & dom & nd & $\min$ & nd & $\operatorname{tr}$ & nd \\
\hline WO-2 & $2 / 24 / 93$ & 600 & nd & dom & $\min$ & maj & poss & $\min$ & nd & nd & nd \\
\hline WO-2 & $2 / 24 / 93$ & 719 & tr & dom & $\min$ & maj & $\operatorname{tr}$ & $\min$ & nd & tr & nd \\
\hline WO-2 & $2 / 24 / 93$ & 815 & tr & maj & $\min$ & maj & $\min$ & $\min$ & nd & tr & nd \\
\hline WO-2 & $2 / 24 / 93$ & 871 & tr & nd & $\operatorname{tr}$ & dom & nd & $\min$ & tr & $\operatorname{tr}$ & nd \\
\hline WO-2 & $2 / 24 / 93$ & 932.3 & nd & nd & nd & tr & nd & maj & nd & dom & nd \\
\hline WO-2 & $2 / 24 / 93$ & $1,001.5$ & $\min$ & poss & nd & dom & nd & $\min$ & nd & poss & nd \\
\hline PW-7 & $6 / 9 / 93$ & 219.3 & tr & dom & $\min$ & maj & poss & $\min$ & tr & nd & nd \\
\hline PW-7 & $6 / 9 / 93$ & 230 & tr & dom & $\min$ & maj & poss & $\min$ & nd & poss & nd \\
\hline TRA-5 & $6 / 9 / 93$ & 69 & $\operatorname{tr}$ & $\min$ & $\min$ & dom & $\min$ & maj & nd & $\mathrm{tr}$ & nd \\
\hline TRA-8 & $6 / 9 / 93$ & 116.5 & poss & dom & $\min$ & maj & nd & maj & nd & tr & nd \\
\hline
\end{tabular}


Table 4.-Mineralogy of particle fraction less than 2 micrometers by X-ray diffraction analysis of samples from selected sedimentary interbeds at the Idaho National Engineering Laboratory-Continued

\begin{tabular}{|c|c|c|c|c|c|c|c|c|c|c|c|}
\hline \multirow{3}{*}{$\begin{array}{c}\text { Site } \\
\text { identifier }\end{array}$} & \multirow{3}{*}{$\begin{array}{c}\text { Date } \\
\text { sampled }\end{array}$} & \multirow{3}{*}{$\begin{array}{l}\text { Interval sampled } \\
\text { (feet below } \\
\text { land surface) }\end{array}$} & \multicolumn{9}{|c|}{ Clay analyses (by abundance category) } \\
\hline & & & \multirow{2}{*}{$\begin{array}{l}\text { Mixed } \\
\text { layer }\end{array}$} & \multirow[b]{2}{*}{ Smectite } & \multirow[b]{2}{*}{ Kaolinite } & \multirow[b]{2}{*}{ Illite } & \multirow[b]{2}{*}{ Chlorite } & \multicolumn{4}{|c|}{ Other minerals } \\
\hline & & & & & & & & Quartz & Calcite & Feldspar & Dolomite \\
\hline TRA-8 & $6 / 9 / 93$ & 204.5 & tr & dom & $\min$ & maj & nd & $\min$ & nd & nd & nd \\
\hline USGS 80 & $2 / 24 / 93$ & 165 & tr & nd & nd & $\min$ & nd & maj & nd & maj & nd \\
\hline USGS 80 & $2 / 24 / 93$ & 175 & tr & dom & $\operatorname{tr}$ & maj & nd & $\min$ & nd & nd & nd \\
\hline USGS 81 & $2 / 24 / 93$ & 27 & $\operatorname{tr}$ & nd & nd & dom & nd & maj & nd & $\operatorname{tr}$ & nd \\
\hline USGS 121 & $6 / 9 / 93$ & $33-34.5$ & poss & maj & $\min$ & dom & tr & $\min$ & nd & tr & nd \\
\hline USGS 121 & $6 / 9 / 93$ & 401 & nd & maj & $\operatorname{tr}$ & maj & poss & $\min$ & nd & tr & nd \\
\hline USGS 121 & $6 / 9 / 93$ & 410.8 & nd & dom & $\min$ & $\min$ & nd & maj & tr & tr & nd \\
\hline USGS 123 & $6 / 9 / 93$ & $10-12$ & poss & dom & $\min$ & maj & tr & $\min$ & nd & $\operatorname{tr}$ & nd \\
\hline USGS 123 & $6 / 9 / 93$ & 112.4 & tr & nd & nd & maj & nd & maj & nd & maj & nd \\
\hline USGS 123 & $6 / 9 / 93$ & 117 & nd & nd & nd & maj & nd & dom & nd & nd & nd \\
\hline USGS 123 & $5 / 14 / 93$ & 420 & $\min$ & $\min$ & nd & dom & $\min$ & maj & nd & poss & nd \\
\hline USGS 123 & $5 / 14 / 93$ & 502 & tr & dom & $\min$ & $\min$ & tr & maj & $\min$ & poss & nd \\
\hline USGS 123 & $5 / 14 / 93$ & 690 & poss & nd & nd & poss & nd & maj & nd & dom & nd \\
\hline RWMC-C1A & $11 / 30 / 93$ & 332.5 & nd & dom & tr & tr & nd & tr & nd & poss & nd \\
\hline RWMC-ClA & $11 / 30 / 93$ & 745.7 & poss & nd & nd & dom & nd & nd & nd & nd & nd \\
\hline RWMC-C1A & $11 / 30 / 93$ & 971 & poss & dom & $\min$ & maj & poss & maj & poss & tr & nd \\
\hline RWMC-C1A & $11 / 30 / 93$ & $1,072.7$ & poss & nd & nd & $\min$ & poss & maj & nd & dom & nd \\
\hline USGS 118 & $2 / 24 / 93$ & 9.4 & $\operatorname{tr}$ & $\min$ & $\min$ & maj & poss & maj & nd & tr & nd \\
\hline USGS 118 & $2 / 24 / 93$ & 237.9 & $\operatorname{tr}$ & dom & tr & $\min$ & nd & $\min$ & nd & poss & nd \\
\hline NRF-7P & $6 / 9 / 93$ & 93 & tr & nd & nd & dom & nd & nd & nd & nd & nd \\
\hline
\end{tabular}


Table 4.-Mineralogy of particle fraction less than 2 micrometers by X-ray diffraction analysis of samples from selected sedimentary interbeds at the Idaho National Engineering Laboratory-Continued

\begin{tabular}{|c|c|c|c|c|c|c|c|c|c|c|c|}
\hline \multirow{3}{*}{$\begin{array}{c}\text { Site } \\
\text { identifier }\end{array}$} & \multirow{3}{*}{$\begin{array}{c}\text { Date } \\
\text { sampled }\end{array}$} & \multirow{3}{*}{$\begin{array}{l}\text { Interval sampled } \\
\text { (feet below } \\
\text { land surface) }\end{array}$} & \multicolumn{9}{|c|}{ Clay analyses (by abundance category) } \\
\hline & & & \multirow{2}{*}{$\begin{array}{l}\text { Mixed } \\
\text { layer }\end{array}$} & \multirow[b]{2}{*}{ Smectite } & \multirow[b]{2}{*}{ Kaolinite } & \multirow[b]{2}{*}{ Illite } & \multirow[b]{2}{*}{ Chlorite } & \multicolumn{4}{|c|}{ Other minerals } \\
\hline & & & & & & & & Quartz & Calcite & Feldspar & Dolomite \\
\hline USGS 99 & $2 / 24 / 93$ & $25-30$ & $\min$ & $\min$ & $\operatorname{tr}$ & dom & nd & maj & nd & tr & nd \\
\hline USGS 103 & $2 / 24 / 93$ & 15 & tr & $\min$ & tr & maj & poss & maj & nd & tr & nd \\
\hline TAN CH-1 & 6/9/93 & 444.5 & nd & dom & nd & nd & $\min$ & nd & $\min$ & nd & nd \\
\hline TAN CH-1 & $6 / 9 / 93$ & 446.5 & poss & maj & nd & tr & nd & tr & dom & nd & nd \\
\hline TAN CH-2 & $6 / 9 / 93$ & 245.5 & nd & dom & nd & nd & poss & $\min$ & nd & $\min$ & nd \\
\hline TAN CH-2 & $6 / 9 / 93$ & 735 & poss & dom & nd & $\operatorname{tr}$ & poss & $\min$ & nd & tr & nd \\
\hline TAN CH-2 & $6 / 9 / 93$ & 977.7 & tr & dom & $\min$ & maj & poss & $\min$ & nd & tr & nd \\
\hline CLC-4A & $10 / 24 / 90$ & $0-1.3$ & $\min$ & $\min$ & maj & dom & nd & tr & tr & nd & nd \\
\hline CLC-4A & $10 / 24 / 90$ & $1.3-2.5$ & maj & dom & maj & dom & poss & maj & maj & nd & tr \\
\hline CLC-4A & $10 / 24 / 90$ & $4.5-5.2$ & maj & maj & maj & dom & nd & $\min$ & $\min$ & tr & poss \\
\hline CLC-4A & $10 / 24 / 90$ & $6.3-7.0$ & maj & dom & maj & dom & poss & maj & maj & tr & poss \\
\hline CLC-4A & $10 / 24 / 90$ & $15.0-16.0$ & maj & maj & maj & dom & poss & maj & $\min$ & tr & poss \\
\hline
\end{tabular}




\section{Table 5.-Clay mineralogy of sediment and vesicle infill by X-ray diffraction analysis of core samples from}

GIN-6, Hwy-1, and USGS 30

[See figure 2 for location of core-hole sites. Samples analyzed April 7, 1970. Type of sample: S, sediment sample, I, vesicle filling in basalt. Clay analyses: min, mineral is minor in abundance; dom, mineral is dominant; nd, mineral was not detected; tr, mineral is present in a trace amount; maj, mineral is major in abundance; poss, mineral is possibly present]

\begin{tabular}{|c|c|c|c|c|c|c|c|c|c|c|}
\hline \multirow{3}{*}{$\begin{array}{c}\text { Site } \\
\text { identifier }\end{array}$} & \multirow{3}{*}{$\begin{array}{l}\text { Type of } \\
\text { sample }\end{array}$} & \multirow{3}{*}{$\begin{array}{l}\text { Interval sampled } \\
\text { (feet below } \\
\text { land surface) }\end{array}$} & \multicolumn{8}{|c|}{ Clay analyses (by abundance category) } \\
\hline & & & \multirow{2}{*}{$\begin{array}{l}\text { Mixed } \\
\text { layer }\end{array}$} & \multirow[b]{2}{*}{ Smectite } & \multirow[b]{2}{*}{ Kaolinite } & \multirow[b]{2}{*}{ Illite } & \multirow[b]{2}{*}{ Chlorite } & \multicolumn{3}{|c|}{ Other minerals } \\
\hline & & & & & & & & Quartz & Feldspar & Calcite \\
\hline Hwy-1 & $S$ & 1,283 & $\min$ & dom & $\min$ & $\min$ & nd & $\min$ & tr & nd \\
\hline Hwy-1 & $S$ & 1,288 & $\min$ & dom & maj & $\min$ & nd & $\min$ & tr & nd \\
\hline GIN-6 & I & 146 & $\min$ & $\min$ & $\min$ & $\operatorname{tr}$ & nd & maj & tr & dom \\
\hline GIN-6 & I & 146 & tr & $\min$ & $\min$ & tr & nd & maj & tr & dom \\
\hline USGS 30 & $S$ & 453 & poss & maj & $\min$ & nd & nd & $\min$ & tr & nd \\
\hline USGS 30 & $S$ & 454 & poss & dom & maj & nd & nd & tr & tr & nd \\
\hline USGS 30 & $S$ & 455 & $\min$ & dom & $\min$ & nd & nd & poss & tr & nd \\
\hline USGS 30 & $S$ & 494 & $\operatorname{tr}$ & dom & maj & maj & nd & $\min$ & $\min$ & nd \\
\hline USGS 30 & $S$ & 495 & $\min$ & dom & $\min$ & $\min$ & poss & $\min$ & tr & nd \\
\hline USGS 30 & $S$ & 521 & $\min$ & dom & maj & $\min$ & nd & $\min$ & tr & nd \\
\hline
\end{tabular}

